\title{
ВПЛИВ КОРУПЦЙНИХ ПРОЯВІВ НА СТАН ЗАХИЩЕНОСТІ ОБ'СКТІВ КРИТИЧНОЇ ІНФРАСТРУКТУРИ ДЕРЖАВИ ВІД ЗОВНІШНІХ ЗАГРОЗ (НА ПРИКЛАДІ ЗАЛІЗНИЧНОГО ТРАНСПОРТУ УКРАЇНИ)
}

\author{
Чередниченко О.Ю., к.е.н., доцент, професор ( Інститут підготовки \\ юридичних кадрів для СБ Украӥни НЮУ ім. Ярослава Мудрого), \\ докторант (УкрДУЗТ)
}

В статті обтрунтовано необхідність мінімізаиії корупиійної складової на розвиток транспортної системи держави, удосконалення системи захисту об'єктів критичної інфраструктури (на прикладі залізничної галузі) в сучасних умовах розвитку держави та суспільства. Встановлено, що мінімізація корупџійної складової при здійсненні господарчої та управлінської діяльності залізничного транспорту позитивно відіб'ється на забезпеченні життєво важливих інтересів людини, громадянина, суспільства і держави. Також констатується, щео корупційна складова $є$ негативним фактором сталого розвитку $і$ гальмом реформ залізниці, знижує рівень системи захищеності об'єктів критичної інфраструктури, як невід'ємної складової системи протидї загрозам національних інтересів держави. Пропонуються шляхи мінімізації впливу корупиії на об'єкти критичної інфраструктури (на прикладі залізничної галузі) та напраџьовано рекомендації щзодо дій керівництва і менеджменту в цьому напрямку з урахуванням кращого світового досвіду й стандартів.

Ключові слова: транспорт, національна безпека, об'єкти підвищеної небезпеки, критична інфраструктура, менеджмент, загрози, ризики, небезпеки, національна економіка, сектор безпеки, корупційні прояви, корупційна складова, залізнична галузь, національні інтереси.

\section{ВЛИЯНИЕ КОРРУПЦИОННЫХ ПРОЯВЛЕНИЙ НА СОСТОЯНИЕ ЗАЩИЩЕННОСТИ ОБЪЕКТОВ КРИТИЧЕСКОЙ ИНФРАСТРУКТУРЫ ГОСУДАРСТВА ОТ ВНЕШНИХ УГРОЗ (НА ПРИМЕРЕ ЖЕЛЕЗНОДОРОЖНОГО ТРАНСПОРТА УКРАИНЫ)}

\section{Чередниченко А.Ю., к.е.н., доцент, профессор ( Институт подготовки юридических кадров для СБ Украины НЮУ им. Ярослава Мудрого), докторант (УкрГУЖТ)}

В статье обоснована необходимость минимизации коррупционной составляющей на развитие транспортной системы государства, совершенствование системы защиты объектов критической инфраструктуры (на примере железнодорожной отрасли) в современных условиях развития государства и общества. Установлено, что минимизация коррупщионной составляющей при осуществлении хозяйственной и управленческой деятельности железнодорожного транспорта положительно отразится на обеспечении жизненно важных интересов человека, гражданина, общества и государства. Также констатируется, что коррупщионная составляющая является негативным фактором устойчивого развития и тормозом реформы железной дороги, снижает уровень системы защищенности 
объектов критической инфраструктуры, как неотъемлемой составляющей системы противодействия угрозам национальным интересам государства. Предлагаются пути минимизаџии влияния коррупции на объекты критической инфраструктуры (на примере железнодорожной отрасли) и наработано рекомендации относительно действий руководства и менеджмента в этом направлении с учетом лучшего мирового опьта и стандартов.

Ключевые слова: транспорт, национальная безопасность, объекты подвышенной безопасности, критическая инфраструктура, менеджсмент, угрозы, риски, опасности, национальная экономика, сектор безопасности, коррупционные проявления, железнодорожная отрасль, национальные интересы.

\title{
THE IMPACT OF CORRUPTION ON THE STATE OF SECURITY OF CRITICAL INFRASTRUCTURE OF THE STATE FROM EXTERNAL THREATS (BY THE EXAMPLE OF RAILWAY TRANSPORT OF UKRAINE)
}

\author{
Cherednychenko O.U., PhD in Economics (Juridical Personnel Training \\ Institute for the Security Service of Ukraine, Yaroslav Mudryi National Law \\ University), doctoral student (USURT)
}

The article substantiates the necessity of minimizing corruption component on the development of transport system of the State, improvement of the system of protection of objects of critical infrastructure (for example, the railway industry) in the modern conditions of development of the State and society. It is established that in the case of minimizing corruption component in carrying out economic and management activity of railway transport, this has a positive impact on providing vital human interests of the citizen, society and the State. Also following that corrupt element is a negative factor for sustainable development and brake reforms of the railway, the system reduces the level of protection of the objects of the critical infrastructure as an integral component of system threats to national interests State. Determined that corruption in the railway infrastructure expressed in terms of: non-targeted and inefficient use of funds; the questionable actions of officials in implementing the economic and financial-economic activities; the manipulation of the selection of priority directions of development of transport infrastructure; lobbying stakeholders in the development and production of imperfect equipment, outdated technology, the embodiment of the secondary project as a priority; rigid centralization of managerial, financial, administrative, personnel levers in the "hands" of senior management; appointment of incompetent persons to managerial, managerial levels; decision-making under the influence and in the interests of representatives of individual financial and industrial groups; populism, adoption of programs, strategies, concepts that can not be implemented in practice. Offers ways minimize corruption at objects of critical infrastructure (for example, the railway industry) and has recommendations for action leadership and management in this direction taking into account the best international dosv.

Key words: transportation, national security, high risk, critical infrastructure, management, threat, risk, hazard, national economy, the security sector, corruption, corruption, the railway sector, the national interests.

Вступ. Історично склалося, що експлуатаційна довжина якої становить наша держава має одну 3 найбільш близько 22 тис. км. Для України розвинених в Європі залізничних мереж, залізничний транспорт на довгострокову 
перспективу залишиться основним перевізником. Транспорт забезпечує потреби населення та економіки у перевезенні пасажирів і вантажів, в тому числі для потреб Збройних Сил України, інших військових формувань та підприємств військово-промислового комплексу держави [1]. Забезпечуючи транспортування вантажів різноманітної номенклатури для підприємств та установ різних форм власності, транспортний комплекс безпосередньо бере участь у формуванні додаткової вартості кінцевого продукту. Крім того, залізничники самі $\epsilon$ споживачами продукції машинобудування, інших виробів промислового комплексу, а це додаткові робочі місця, відрахування до бюджетів всіх рівнів.

Безперечне і те, що транспортний відіграє важливу роль у вирішенні соціальних питань; нерідко виконує функції спонсора, наприклад для спортсменів, представників мистецтва, захисників нашої держави.

Таким чином, підприємства залізничного транспорту вважаються критично важливими для національного господарства, виведення із ладу або руйнування яких може мати вплив на національну безпеку і оборону, природне середовище, призвести до значних матеріальних та фінансових збитків, людських жертв [2].

Нажаль зношеність і застарілість основних фондів, неефективність діяльності більшої частини відомчого менеджменту, a інколи i навмисні протиправні дії посадових осіб призвели до проблем 3 забезпеченням потреб населення та економіки у перевезенні пасажирів і вантажів.

Постановка проблеми. 31 грудня 2015 року на базі Державної адміністрації залізничного транспорту України створено ПАТ «Українська залізниця» (в теперішній час акціонерне товариство) i, таким чином, розпочато реформування залізничного транспорту держави відповідно до рекомендацій та стандартів
Європейського співтовариства [3]. Саме потребою модернізації залізничної інфраструктури i рухомого складу, підвищенням його ефективності та здатності виконувати вищенаведені завдання викликана робота 3 реформування українських залізниць. При цьому одними 3 найважливіших завдань у роботі українських залізниць є безпека руху поїздів, захищеність інфраструктури залізничного транспорту від терористичних актів та інших незаконних втручань, від техногенних катастроф та інших надзвичайних ситуацій.

Проблеми захищеності об'єктів критичної інфраструктури $\epsilon$ актуальними не тільки для нашої країни, яка по суті знаходиться у стані «гібридної» війни 3 сусідньою державою, а й для країн Європейського Союзу, США, Великобританії та інших цивілізованих країн 3 потужною економікою та розвинутою соціальною складовою суспільства. Каталізатором цього також $є$ глобальна фінансова та міграційна кризи. Особливої актуальності вказане питання набуває в період протистояння країн цивілізованого світу 3 країнами, які підтримують тероризм, 3 країнами агресорами, окремими організаціями та групами терористичного спрямування.

Тільки маючи сильну економіку можна ефективно протистояти вказаним викликам і загрозам. Вибудувати міцну економіку більшості країн Європейської спільноти, США та Великобританії національним урядам вдалося шляхом захисту національних інтересів, реальною боротьбою 3 економічною злочинністю, відмиванням «брудних коштів», податковими злочинами, явищами, які можна замінити одним тлумаченням «корупційні дії або корупційні прояви».

Аналіз міжнародного досвіду боротьби 3 корупцією свідчить про те, що за сучасних умов прояви корупції стали тими чинниками, що створюють реальну загрозу національній безпеці та демократичному розвитку більшості країн світу, негативно впливають на всі сторони 
суспільного життя. За даними $\mathrm{OOH}$ щорічний обсяг хабарів у світовому масштабі складає 1 триліон доларів США, а світова економіка втрачає 2,6 триліона доларів США із-за корупції. За словами Генерального секретаря ООН Антоніу Гутеррешу вказані фінансові засоби складають більше 5\% глобального ВВП [4]. Не викликає сумніву те, що основними країнами-лідерами в цьому ганебному списку є країни які не прагнуть до реформ національної економіки, не проводять реальних заходів 3 очищення економіки від корупційних проявів, хоча активно використовують гасла та запевнюють про активну боротьбу із економічною злочинністю.

Аналіз останніх досліджень i публікацій. Безпека інфраструктури розглядається в роботах таких вчених як В.Л. Дикань, І.Л. Назаренко, P.А. Кожевніков, 3.П. Межох, Н.П. Терьошина, С.П. Міщенко, Д.С. Бірюков, С.I. Кондратов, О.М. Суходоля. [5-8] та ін. Протидії несанкціонованим втручанням в роботу залізничного транспорту, терактам та диверсіям, стану захищеності об'єкті транспортної інфраструктури приділяли увагу О.Ю. Чередниченко, В.З. Дитюк, А.Ю. Журавльов [9-11] та ін. Наукові праці щодо боротьби 3 корупційними проявами, в тому числі на транспорті, протидії злочинам у сфері службової діяльності, пов'язаною 3 наданням публічних послуг, економічної безпеки залізничного транспорту публікували Г. Беккер, В.Л. Дикань, О.Ю. Чередниченко, Д.Г. Михайленко [12-16] та ін.

В той же час, проблеми впливу корупційних проявів на стан захищеності об'єктів критичної інфраструктури від внутрішніх та зовнішніх загроз залишаються поза увагою більшості науковців, а роботі 3 пошуку шляхів їх подолання приділяється недостатньо уваги.

У зв'язку з цим метою статі $\epsilon$ дослідження впливу на стан захищеності об'єктів критичної інфраструктури від внутрішніх та зовнішніх загроз корупційних проявів, неправомірних дій посадових осіб залізничної галузі пов'язаних з наданням публічних послуг, що в цілому негативно впливає на діяльність акціонерного товариства.

Виклад основного матеріалу. В сучасних умовах в українському суспільстві 3 позитивом та надією сприймаються інфраструктурні проекти та намагання розбудови об'єктів критичної інфраструктури, спрямованих на покращення якості, доступності та надійності «артерій економіки держави»транспортного комплексу країни. В той же час, нажаль більшість новаторських проектів залишається саме проектами та не втілюються в життя, а окремі позитивні досягнення в сфері критичної інфраструктури не можна вважати системними, а це в свою чергу не дозволяє вивести галузь на рівень кращих світових стандартів, ефективно модернізувати іiі діяльність.

Однією з основних причин цього $\epsilon$ корупційна складова. За оцінками не тільки громадян, a i фахівців 3 протидії корупції це негативне явище проникло вже і до базових об'єктів промисловості, критичної інфраструктури, де раніше прояви корупції були значно нижче чим в органах влади та управління, контролюючих та правоохоронних органах, судах. При цьому, наміри менеджменту управлінської ланки щодо зниження рівня корупційних ризиків на об'єктах транспортної інфраструктури так i залишаються нереалізованими, або реалізуються безсистемно та вибірково. Корупція стала основною причиною відсутності успіхів в процесі реформування транспортної галузі, причому це стосується як підприємств державної форми власності, так i недержавної.

Hi у кого не викликає заперечень, що пошкодження критичної інфраструктури, тї руйнування або порушення роботи окремих ланцюжків можуть бути результатами стихійних лих, 
тероризму, несанкціонованого злочинного втручання в їх діяльність. В той же час, корупційні дії посадових осіб, наприклад в процесі закупівель неякісної продукції для рухомого складу чи для відбудови шляхів сполучень, як правило, не розглядаються як причина виходу із ладу рухомого складу чи інфраструктури. А якщо таки дії посадових осіб набувають системного характеру, то це може призвести і до аварій, і катастроф чи взагалі до руйнування критичної інфраструктури.

На нашу думку, слід відмітити пряму залежність рівня корупції на об'єктах критичної інфраструктури і рівня ïх захищеності від негативного впливу вищезгаданих факторів, та й взагалі готовності протистояти викликам національній безпеці на сучасному етапі розвитку держави.

Корупційні прояви на об'єктах залізничної інфраструктури виражаються через:

- нецільове та неефективне використання коштів, в тому числі бюджетних, передбачених на потреби об'єктів критичної інфраструктури (наприклад: закупівля недоброякісних паливно-мастильних матеріалів, харчів, обмундирування, обладнання, використання для ремонтновідновлювальних i регламентних робіт контрафактних запчастин, вузлів та механізмів, створення різного «надбудов» у вигляді додаткових керівних ланок 3 завищеним бюджетом їх фінансування і т. ін.);

- сумнівні дії посадових осіб об'єктів критичної інфраструктури в процесі здійснення господарської та фінансово-економічної діяльності (наприклад: закупівля відновленої та модернізованої, вживаної техніки і обладнання 3 послідуючою передачею користувачам під виглядом нової чи новоствореної);

- маніпуляції 3 вибором пріоритетних напрямків розвитку чи розбудови об'єктів транспортної

інфраструктури (наприклад: закупівля, в тому числі наявність надлишкової техніки, або іï окремих типів замість дійсно необхідних типів локомотивів, рухомого складу);

- лобіювання зацікавленими особами розробки i виробництва недосконалої техніки, за застарілими технологіями, втілення другорядних проектів як пріоритетних;

$$
\text { - жорстка }
$$

управлінських, адміністративних, кадрових важелів в «руках» менеджменту вищої ланки акціонерного товариства, що позбавляє можливості оперативного керування підприємствами на місцях;

- призначення на керівні, управлінські ланки некомпетентних осіб, брак професіоналів та мотивованих спеціалістів, викликаний впливом таких факторів як «кумівство», «політична доцільність», «квотний принцип» і т. ін.;

- прийняття рішень під впливом та в інтересах представників окремих фінансово-промислових груп, в тому числі іноземних, які негативно впливають на розбудову та функціонування об'єктів критичної інфраструктури;

- популізм, прийняття програм, стратегій, концепцій, які неможливо реалізувати на практиці, а їх складові не впливають позитивно на діяльність транспортного комплексу (наприклад: в теперішній час Головним слідчим управлінням Національної поліції України здійснюється досудове розслідування №42018000000003032 від 4.12.2018 р. за фактами привласнення засобів в особливо великих розмірах посадовими особами ПАТ «Українська залізниця» при організації залізничного пасажирського сполучення м. Київ - Міжнародний аеропорт «Бориспіль»).

Наведений список не є остаточним, автор намагався акцентувати увагу на проблему взагалі та навів найбільш значимі фактори, які послабляють як об'єкти критичної інфраструктури так i транспортну галузь в цілому, призводить 
до зменшення iii потенціалу та втрати керованості. А це в свою чергу не дозволяє у разі необхідності мобілізуватися для протистояння сучасним зовнішнім та внутрішнім викликам, надійно i небезпечно функціонувати транспортному комплексу, який сам собою вже $\epsilon$ загрозою із-за специфіки технологічного процесу; наявності уразливих у диверсійнотерористичному відношенні об'єктів; використання чи перевезення небезпечних речовин у великих обсягах (наприклад: паливно-мастильних матеріалів, небезпечних та отруйних речовин) тощо.

На думку автора, слід акцентувати увагу на таку важливу річ: безкарність та спокуса отримати значну вигоду від протиправних дій $\epsilon$ підгрунтям для подальшої корумпованості менеджменту транспортного комплексу та стагнації галузі. Це можна підтвердити i теоретично, використавши формулу запропоновану Г. Беккером [12]:

$$
\mathrm{U}=\mathrm{D}-\mathrm{pf}
$$

де D- дохід, від скоєного злочину (корупційної дії),

р-вірогідність покарання злочинця,

$\mathrm{f}$-грошовий еквівалент покарання.

За минулі три роки ні одного менеджера вищої управлінської ланки АТ «Укрзалізниця» не було притягнуто до кримінальної чи адміністративної відповідальності за корупційні дії, що і так свідчить про недоцільність використання формули Г. Беккера.

Без реальних, зрозумілих і чесних дій керівництва та менеджменту, i як наслідок мінімізації корупційних проявів, можна остаточно втратити систему керованості підприємства (установи) галузі, систему захищеності об'єктів критичної інфраструктури. Згідно закону України «Про залізничний транспорт» [1] державне регулювання в області залізничного транспорту здійснюється шляхом організації й забезпечення військових і спеціальних залізничних перевезень, керівництва мобілізаційною підготовкою й цивільною обороною, покладання обов'язків по перевезенню на конкретних перевізників у випадку виникнення загрози безпеки держави. На законодавчому рівні закріплені питання організації роботи в надзвичайних ситуаціях, спеціалізованих підрозділів, запасу матеріальних і технічних засобів для їхньої ліквідації.

Висновки. Система безпеки залізничного транспорту є найважливішої складової національної безпеки, однак поки ця тема перебуває на периферії інтересів менеджменту залізничного транспорту.

В сучасних умовах складних соціально-економічних перетворень, впливу зовнішніх та внутрішніх факторів на стан національної безпеки України, набуває особливої актуальності саме питання захищеності об'єктів життєзабезпечення та критичної інфраструктури держави, а для цього треба подолати не тільки технологічне відставання, модернізувати галузь, а й усунути чи мінімізувати негативні фактори, ключовими 3 яких $є$ корупційні прояви та ризики.

У світі вже напрацьовані й діють «правила гри» в цьому напрямку та стандарти і рекомендації щодо мінімізації цих викликів, які вважаються одними із головних загроз i ризиків для всіх цивілізованих країн. Інструменти успішної протидії корупції вже давно відомі та апробовані міжнародною спільнотою.

Україна, незважаючи на ряд об'єктивних і суб'єктивних факторів, залишається транспортною державою, має велику кількість об'єктів критичної інфраструктури від безпечної роботи яких залежить не тільки безпека держави, а й безпека багатьох країн європейського континенту та інших країн прилеглих регіонів. 
ПЕРЕЛІК ВИКОРИСТАНИХ ДЖЕРЕЛ

1. Про залізничний транспорт : Закон України від 4 липня 1996 р. № 273/96-ВР // Відомості Верховної Ради України. - 1996. - № 40. - Ст. 183.

\section{2. Чередниченко}

О.Ю. Реформування країни, як головна стратегія подолання загроз національній безпеці України на сучасному етапі розвитку держави / А.Ю. Чередниченко // Вісник економіки транспорту i промисловості -2016. - №56. - С. 88-96

3. Зелена книга 3 питань захисту критичної інфраструктури в Україні : зб. мат-лів міжнар. експерт. нарад / упоряд. Д. С. Бірюков, С.І. Кондратов; за заг. ред. О. М. Суходолі. - К. : НІСД, 2015. - 176 с.

4. Промова Генсека ООН Антоніу Гуттереша 3 нагоди міжнародного дня боротьби 3 корупцією [Електронний ресурс]. - Режим доступу: https://news.un.org/ ru/ content/unnewsletter-subscribe

5. Дикань В.Л. Обеспечение конкурентоспособности

железнодорожного транспорта основной составляющей экономической безопасности / В.Л. Дикань, И.В. Воловельская // Вісник Одеського національного університету імені I.I. Мечникова. - 2016. - Серія. Економіка. - Т.21. - Вип. 1 - С. 82-85.

6. Дикань В.Л. Комплексна методика визначення рівня економічної безпеки, оцінки ризиків та ймовірності банкрутства підприємства : монографія / В.Л. Дикань, І.Л. Назаренко. - Харків: УкрДАЗТ, 2011. - 142 с.

7. Кожевников

Экономическая

P.A. железнодорожного транспорта: учебное пособие для вузов железнодорожного транспорта / Р.А. Кожевников, З.П. Межох, Н.П. Терешина. - М. : Маршрут, 2005. $-326 \mathrm{c}$.

8. Міщенко С.П. Напрями забезпечення економічної безпеки залізничного транспорту / С.П. Міщенко /
Вісник економіки транспорту та промисловості. -2011. - № 34. - С. 206-209.
9. Чередниченко
$\mathrm{O}$.
Ю. Несанкціоновані втручання в роботу залізничного транспорту, як фактор нанесення шкоди державним інтересам України / О.Ю. Чередниченко, А.О. Чередниченко // Вісник економіки транспорту і промисловості. - 2014. - Вип. 47. - C. 62-66.

10. Дитюк В.3. Терористична діяльність на об'єктах транспортної інфраструктури у контексті подій на сході України: аналіз проявів / В.З. Дитюк // Наукові записки Львівського університету бізнесу та права. - 2014. - № 12. - С. 265268.

11. Журавльов А.Ю. Поняття та сутність злочинів, пов'язаних із терористичною діяльністю / А.Ю. Журавльов // Митна справа. - 2014. №3(2). - С. 70-76.

12. Беккер Г.С. Человеческое поведение: экономический подход/ Г.С. Беккер. - М.: ГУ ВШЭ, 2003. — 672c.

13. Дикань В.Л. Обеспечение конкурентоспособности

железнодорожного транспорта как основной составляющей его экономической безопасности / В.Л. Дикань, И.В. Воловельская // Вісник Одеського національного університету імені I.I. Мечникова. - 2016. - Серія. Економіка. - Т.21. - Вип. 1 - С. 82-85.

$$
\text { 14. Чередниченко О. Ю. }
$$

Декриміналізація окремих злочинів, як один із шляхів підвищення рівня безпеки на залізничному транспорті та забезпечення відшкодування збитків від несанкціонованого втручання в діяльність об'єктів критичної інфраструктури / О. Ю. Чередниченко // Вісник економіки транспорту і промисловості. - 2018. - № 61. - C. 248-255.

15. Михайленко Д.Г. Теоретичні аспекти трансформації інституту корупційних злочинів / Д.Г. Михайленко // Актуальні проблеми держави і права. 2014. - Вип. 74. - С. 338-346. 
16. Про Стратегію національної безпеки України: Указ Президента України від 26.05.2015 року № 287/2015 // Офіційний вісник України. -09.06.2015. №43. - Стаття 1353. - С. 38

\section{REFERENCES}

1. Pro zaliznychnyj transport : Zakon Ukrajiny vid 4 lypnja 1996 r. \# 273/96VR [On railway transport: Law of Ukraine dated July 4, 1996 No. 273/96-VR]. Information from the Verkhovna Rada of Ukraine. No. 40.

2. Cherednichenko O.Yu. (2016) Reformuvannja krajiny, jak gholovna strateghija podolannja zaghroz nacionaljnij bezpeci Ukrajiny na suchasnomu etapi rozvytku derzhavy . [Reform of the country as the main strategy to overcome threats to national security of Ukraine in the current development state]. The bulletin of Transport and Industry Economics. No 56, p. 88-96

3. Zelena knygha $\mathrm{z}$ pytanj zakhystu krytychnoji infrastruktury v Ukrajini (2015) [Green Paper on critical infrastructure protection in Ukraine]. Collection of materials of the international expert meeting [order. D.S. Biryukov, S.I. Kondratov; for community edit O. M. Sukhodoli]. K.: NISS. (in Ukrainian)

4. Promova Ghenseka OON Antoniu Ghutteresha z naghody mizhnarodnogho dnja borotjby $\mathrm{z}$ korupcijeju [Address by UN Secretary General Antonio Gutteresha on the occasion of the International Day for the Fight Against Corruption]. Available at: https://news.un.org/ ru/ content/unnewsletter-subscribe

5. Dykan V.L., Volovelskaya I.V. (2016) Obespechenie konkurentosposobnosti zheleznodorozhnogo transporta kak osnovnoy sostavlyayushchey ego ekonomicheskoy bezopasnosti [Ensuring competitiveness of rail transport as a major component of its economic security]. Bulletin of the Odessa National University named after I.I. Mechnikov. Series. Economy. Vol. 21., No.1, pp. 82-85.
6. Dykan V.L., Nazarenko I.L. (2011) Kompleksna metodyka vyznachennja rivnja ekonomichnoji bezpeky, ocinky ryzykiv ta jmovirnosti bankrutstva pidpryjemstva: monoghrafija [Integrated method for determining the level of economic security, risk assessment and probability of bankruptcy of the enterprise: monograph]. Kharkiv: Ukrainian State Academy of Railway Transport. (in Ukrainian)

7. Kozhevnikov R.A. Mezhokh Z.P., Tereshina N.P. (2005) Ekonomicheskaya bezopasnost' zheleznodorozhnogo transporta: uchebnoe posobie dlya vuzov zheleznodorozhnogo transporta [Economic security of railway transport: study guide for universities of railway transport]. M.: Route. (in Russian)

8. Mischenko S.P. (2011) Naprjamy zabezpechennja ekonomichnoji bezpeky zaliznychnogho transportu [Areas of ensuring economic safety of rail transport]. The bulletin of Transport and Industry Economics. No34., pp.206-209

9. Cherednichenko O. Yu., Cherednichenko A.O. (2014) Nesankcionovani vtruchannja $\mathrm{v}$ robotu zaliznychnogho transportu, jak faktor nanesennja shkody derzhavnym interesam Ukrajiny [Unauthorized interference with the operation of rail transport as a factor in causing damage to the state interests of Ukraine]. The bulletin of Transport and Industry Economics. No.47, pp.62-66

$$
\text { 10. Dytyuk V.Z. }
$$

Terorystychna dijaljnistj na ob'jektakh transportnoji infrastruktury u konteksti podij na skhodi Ukrajiny: analiz projaviv [Terrorist activity at the objects of transport infrastructure in the context of events in eastern Ukraine: analysis of manifestations]. Scientific notes of Lviv University of Business and Law. No.12, pp. 265-268.

11. Zhuravlev A.Yu. (2014) Ponjattja ta sutnistj zlochyniv, pov'jazanykh iz terorystychnoju dijaljnistju [The concept and nature of crimes related to terrorist activity]. Customs Affairs. No3(2), pp. 70-76.
12. Becker
G.S.

Chelovecheskoe povedenie: ekonomicheskiy 
podkhod [Human behavior: an economic approach]. M .: State University Higher School of Economics. (in Russian)

13. Dykan V.L., Volovelskaya I.V. (2016) Obespechenie konkurentosposobnosti zheleznodorozhnogo transporta kak osnovnoy sostavlyayushchey ego ekonomicheskoy bezopasnosti [Ensuring competitiveness of rail transport as a major component of its economic security]. Bulletin of the Odessa National University named after I.I. Mechnikov. Series. Economy. Vol. 21., No.1, pp. 82-85.

14. Cherednichenko O.Yu. (2018)

Dekryminalizacija okremykh zlochyniv, jak odyn iz shljakhiv pidvyshhennja rivnja bezpeky na zaliznychnomu transporti ta zabezpechennja vidshkoduvannja zbytkiv vid nesankcionovanogho vtruchannja $v$ dijaljnistj ob'jektiv krytychnoji infrastruktury
[Decriminalization of individual crimes as one of the ways to increase the level of safety in rail transport and to provide compensation for damage from unauthorized interference with the operation of critical infrastructure objects]. The bulletin of Transport and Industry Economics. No.61, pp. 248-255.

15. Mikhailenko D.G. Teoretychni aspekty transformaciji instytutu korupcijnykh zlochyniv [Theoretical Aspects of the Transformation of the Institute of Corruption Crimes]. Actual problems of state and law. No. 74, pp. 338-346.

16. Pro Strateghiju nacionaljnoji bezpeky Ukrajiny: Ukaz Prezydenta Ukrajiny vid 26.05.2015 roku \# 287/2015 [About the Strategy of National Security of Ukraine: Decree of the President of Ukraine dated 05/26/2015 № 287/2015]. Official Bulletin of Ukraine. No43, Article 1353, pp. 38 